Board of Governors of the Federal Reserve System

International Finance Discussion Papers

Number 643

August 1999

\title{
TRADE PRICES AND VOLUMES IN EAST ASIA THROUGH THE CRISIS
}

\author{
Marvin Barth and Trevor Dinmore
}

NOTE: International Finance Discussion Papers are preliminary materials circulated to stimulate discussion and critical comment. References to International Finance Discussion Papers (other than an acknowledgment that the writer has had access to unpublished material) should be cleared with the author or authors. Recent IFDPs are available on the Web at www.bog.frb.fed.us. 


\title{
TRADE PRICES AND VOLUMES IN EAST ASIA THROUGH THE CRISIS
}

\author{
Marvin Barth and Trevor Dinmore*
}

\begin{abstract}
This paper presents a break-down of the export and import performance of select East Asian countries into price and volume effects. The results show that in aggregate, the decline in export revenue experience by these countries in 1998 was largely due to a 9.1 percent fall in prices, and that export volume actually rose. Similarly, while the import volume of these countries did fall in 1998, the decline was not as great as in the dollar value of those imports, but reflected a greater slide in import prices of 10.8 percent. The fall in import and export prices in the East Asian region began in 1996, before the crisis, but intensified in the Summer and Fall of 1997 as the currency crisis unfolded and has continued through the Spring of 1999. Since the fall in import prices was apparently greater than the corresponding fall in export prices, these countries have collectively seen an improvement in their terms of trade during the crisis, reversing pre-crisis declines. The six countries that form the heart of this study were the source of 12.5 percent of US non-oil imports in 1998 , and the accrued benefit to the United States of this price collapse may have been as much as a quarter of the value of these imports over two years.
\end{abstract}

Keywords: Asian Crisis, Trade Prices

*The first author is an economist in the Division of International Finance, Board of Governors of the Federal Reserve System, who can be reached post at Mail Stop 20, Federal Reserve Board of Governors, Washington, DC 20551, or by e-mail at marvin.barth@frb.gov. The second author is a former research assistant at the same institution. The views in this paper are solely the responsibility of the authors and should not be interpreted as reflecting the views of the Board of Governors of the Federal Reserve System or of any other person associated with the Federal Reserve System. 


\section{Introduction}

Following the large devaluations by Indonesia, Korea, Malaysia, the Philippines and Thailand and the accompanying depreciations of the currencies of Singapore and Taiwan in Summer/Fall 1997, all but one of these countries have experienced contractions in US dollar denominated export revenues. The contraction in export revenue has occurred as domestic demand in these countries has plummeted. This is slightly perplexing given that these are small open economies, and their devaluations should be expected to spur greater export revenue, at least in the short run, as was the case with Mexico in 1994/95. As a first step in analyzing the contraction in export and import value, it is useful to break them down into price and volume components.

This paper will examine export and import prices and volumes since 1995, from the period immediately preceding the crisis, through the end of 1998. The largest problem one faces in such a study is finding the appropriate data. For this reason, the study is limited to the Asian countries for which data on either trade prices or volumes were available in some form. Those countries are Hong Kong, Indonesia, Korea, Singapore, Taiwan and Thailand. The Philippines is also examined, but due to shortcomings of its data, it is excluded from the aggregated results.

The results of this study show that for the six countries that form the basis of the analysis, export prices are mostly to blame for the poor export performance of these countries. The export prices of these six countries, aggregated by chain-weighted trade shares, fell by 4.8 percent in 1997 and by a further 9.1 percent in 1998. The fall in aggregated export prices is even more spectacular when US import shares are used as chain-weights: a drop of 9.5 percent in 1997 and another 16.6 percent in 1998. Thus, while aggregated export revenue for these six countries was nominally up 6.1 percent in 1997 and fell 3.6 percent in 1998, export volumes rose by 8.8 and 0.7 percent over those two periods, respectively.

The implications of the fall in Asian export prices is non-trivial, and it is likely an important contributing factor to the low rate of US inflation over this period. Non-oil imports of the United States from these six countries in 1998 totaled $\$ 107.9$ billion, roughly 12.5 percent of US non-oil imports during the period. Had these imports been purchased at 1996 prices the import bill would have been $\$ 143$ billion, a savings to US importers of 24.5 percent, according to the aggregated results of this study.

Similarly, while nominal imports of these six countries fell by 15.2 percent during 1998 , their import volume declined by only 9.6 percent. The greater fall in nominal imports was mostly due to a 10.8 percent fall in the import prices of these countries.

The organization of this study is as follows. Section II discusses data sources and issues: what data are available for each of the seven countries listed above, and what the relevant merits and shortcomings of each data type are. Section II may be skipped by readers focused on the results of the study. Section III then uses these data to examine the trade performance of each country individually. Data from six of these countries are then used in Section IV to construct aggregate indices of trade performance for the East Asian region, and the results of this aggregation are 
analyzed. Section $\mathrm{V}$ examines the validity and nature of the astounding declines in both import and export prices of the region over the past three years. Finally, Section VI concludes and summarizes.

\section{Data Sources \& Issues}

Reliable data on export and import prices or volumes for East Asian countries is difficult to find. Often one must rely on data which is less than ideal to gain any insight on the underlying trends in these variables. Some of the countries examined here have extensive data, but reliability is always a concern. For other countries, finding any data at all is difficult. While these problems make it difficult to make pronouncements about the exports and imports of any individual country, by examining these countries in cross section, one can use the data across countries to at least validate the general trend of data within countries.

Regrettably, two countries which should be included in this study, China (PRC) and Malaysia are not, due to a complete lack of data. Also, while the Philippines is included in the country-bycountry analysis in Section III, the inference is limited by the type of the data available, and for this reason it is omitted from the aggregate results in section IV. Data for Thailand is available for only part of the period covered by this study, hence, the aggregated results include Thailand for only the period 1997 through 1998. The data that are available for each of the countries in this study are discussed below. Readers wanting more detail are referred to the data appendix.

\section{Hong Kong}

Hong Kong has a variety of data available whose quality are likely among the best in this study. Unit values of both exports and imports in HK dollars are available on a monthly basis, as are export and import volumes. In addition, there are National Income and Product Accounts (NIPA) data available on both real and nominal export and imports of goods and services. The official unit value data were converted to US dollar denominated prices using an index of the monthly average exchange rate. Implied unit values were created using the official volume data in combination with monthly nominal merchandise trade data. Similarly, implied volumes were created with the official unit value data. NIPA deflators for both exports and imports of goods and services were created from the real and nominal NIPA figures and converted to US dollars by the quarterly average exchange rate.

$\underline{\text { Indonesia }}$

Data for Indonesia are not only rare, but require a large dose of skepticism in interpreting, due to numerous questions about their quality. On a monthly basis, only wholesale prices of exports and imports in rupiah are available. Wholesale export prices are available for both total exports and non-oil/gas exports. No customs data on prices, nor any data on volumes are available. NIPA data on real and nominal exports and imports of goods and services are available in rupiah. The wholesale prices were converted to US dollars using an index of the average monthly exchange rates, and using those in combination with monthly data on nominal merchandise exports and imports volumes were created. The NIPA import and export deflators were created using the nominal and 
real NIPA data along with average quarterly exchange rates.

\section{$\underline{\text { Korea }}$}

Korea has plenty of data available at relatively high frequencies. Indices for export and import prices in won are available on a monthly basis, as are indices for volumes of exports and imports. NIPA data for real and nominal exports and imports of goods and services are available too. Using an index of monthly average exchange rates, the price indices were converted to US dollars, and in combination with nominal trade data these were used to calculate implied merchandise trade volumes. Implied unit values for imports and exports were derived from the official volume indices and nominal merchandise trade data. NIPA deflators for exports and imports of goods and services were implied by the NIPA data available and quarterly average exchange rates.

\section{Philippines}

The Philippines has no monthly data on either prices or volumes for trade. The only data available are nominal merchandise exports and imports on a monthly basis, and real and nominal NIPA data for trade in goods and services. The Philippines also published its NIPA export and import deflators in pesos. The NIPA deflators were converted to US dollars using an index of the quarterly average annual exchange rate. Due to problems with NIPA deflators for goods and services (noted below), inference on the Philippines is limited since we have no other data sources.

\section{Singapore}

Singapore has extensive monthly data on both nominal and real exports and imports, divided by category. Singapore also has price indices for total exports and imports and for each of these categories divided by type of good. All data are in Singapore dollars. No NIPA data on trade are available for Singapore. Total export and total import price indices were converted to US dollars with an index of the monthly average exchange rate. Unit value indices, denominated in US dollars, for non-oil exports, non-oil domestic exports and non-oil imports were constructed from the corresponding nominal and real data in Singapore dollars, and converted to US dollars with an index of the monthly average exchange rate.

\section{Taiwan}

Taiwan has plentiful monthly data on export and import prices and volumes. Official price indices, denominated in NTD, are available for both exports and imports, as well as official unit value indices for each. A quantum index of export volume and a corresponding index of import volume are also available. Quarterly NIPA data for nominal and real exports and imports of goods and services are available in New Taiwan dollars. The official price and unit value indices were converted to US dollar indices through division by a nominal NTD/US dollar exchange rate index. In addition to the official volume data, implied trade volumes were created by dividing nominal exports and imports by the respective official price indices for each. Implicit export and import price deflators for goods and services were derived from the NIPA data in conjunction with the quarterly 
average nominal exchange rate.

Thailand

No NIPA data is available in Thailand, but the Bank of Thailand does now produce monthly export and import unit value and volume indices in US dollars. Unfortunately, these series only begin in January 1996. This does, however, predate the crisis. From the export and import unit value data, in combination with monthly data on nominal exports and imports, implied trade volumes were calculated. Similarly, implied unit value indices were created from the nominal trade data and the volume trade data.

\section{$\underline{\text { Data Issues }}$}

Since it is the purpose of this study to examine the response of trade variables through the course of the crisis, it is preferable to have monthly data. Beyond that there are a variety of issues that may call data into question. The remainder of this section will discuss the merits and shortcomings of the various types of data that are available for these countries.

The first issue of importance is that of unit value indices versus price indices. Unit value indices are derived by dividing nominal values by real values or by volumes. Price indices are derived by tracking the change in nominal values of a fixed basket of goods. Both have their relative merits.

A unit value index gives an accurate measure of the change in the nominal value of the goods that the country is exporting or importing at each moment in time if volumes are held fixed. However, changes in the composition of goods exported or imported affect this picture. This has its down side: if all goods prices remain constant, but a country imports all expensive goods one year and all cheap goods the next, a unit value index of imports will misleadingly suggest that prices are falling. In general, this would not be appropriate. However, this property of unit values does contain useful information. If one has an associated price index as well, a large change in unit values that is not present in prices strongly suggests that a country is engaging in export/import substitution. For instance, in Korea import prices fell by much more than did implied unit values of imports during the first part of the crisis. This suggests that despite the fall in prices, Korea was not benefitting as much as it could because of the goods it was importing, it was choosing the relatively expensive ones. However, as the crisis wore on, there is evidence of import substitution to cheaper goods: since March 1998 the import unit values for Korea have fallen by more than the import price index.

Since it is the purpose of this paper to analyze the behavior of prices of goods being imported to and exported from Asian countries, price indices based on fixed baskets of goods are preferable. With a fixed basket of goods as the reference, composition effects are minimized. There can be problems with the baskets, however. If the basket of goods selected to base the index is too small, or is not representative of the goods that a nation trades, it will inaccurately reflect the behavior of the export and import prices in portends to represent. Ideally one would like to see the basket 
changed periodically to reflect changes in the composition of trade, but not too frequently such that the price index approaches a unit value. Further, one would like to see that the basket is large enough to sufficiently cover the variety of goods traded by the nation. Discussions with representatives from the central banks of some of these countries, and with the US Bureau of Labor Statistics suggest that for the most part, the price indices available from these countries are constructed properly, but coverage and data sampling techniques may lead to some distortion. Hence, the price indices available may not be ideal, but they should be reasonably representative of trend export and import prices for these countries.

Another general data issue is the usefulness of NIPA price deflators. NIPA deflators for exports and imports have three drawbacks. First, they suffer from the same composition effect problems as unit value measures. Second, they are less frequent, available at best on a quarterly basis. This inhibits ones ability to analyze the dynamic behavior of these prices through the crisis.

The third shortcoming of NIPA data is that it includes services, which corrupts the picture since prices for services may be difficult to measure and may behave very differently from merchandise. The Philippines illustrates this well. While monthly data on merchandise exports indicate that the Phillippines registered robust export growth in 1998 in nominal terms (up 16.9 percent, lower than the 18.3-to-29.3 percent growth recorded in the three previous years, but still impressive), the NIPA data show a dramatic fall in both nominal and real exports due to the inclusion of services. What is responsible for the drop off in services? Further investigation into Balance of Payments data shows that this is largely the result of peso conversion of foreign currency deposits, which shows up in the export services account. Hence, it is difficult to interpret the Philippine NIPA export data which implies that in both real and nominal terms exports fell, while prices rose. This is unfortunate in the case of the Philippines, since we do not have any other data on prices or volumes. For all other countries we have one or more forms of monthly data on either prices or volumes that can be used instead of the possibly misleading NIPA data.

A final data issue, which fortunately is confined to Indonesia is that of using wholesale export and import prices. Indonesia has no customs data for export or import prices, and its only monthly data for such prices are wholesalers import and export prices. The problem with such data, particularly for imports, is that they may be corrupted by local costs. That is, the import wholesale price index may be including the cost of transporting the goods from the port to an inland warehouse. In this case, the wages of truck drivers, volatile gasoline prices, variable local taxes and tolls may all distort the picture one receives of the import prices. During the crisis period this is no small issue for Indonesia since gasoline shortages due to a lack of internal refining capacity may have greatly exaggerated wholesale import prices. Unfortunately, there is little that can be done about this problem since we have no other trade price data for Indonesia, except NIPA data whose shortcomings have already been reviewed. This concern is mitigated (or magnified, depending on your perspective) by the general skepticism with which one must view any Indonesian data, due to quality-of-collection and reliability issues.

In the individual country results of Section III and the aggregate results of Section IV below, the analysis focuses where possible on monthly export and import price indices. If such data are not 
available, monthly unit values are used. In the case of Indonesia, wholesale export and import prices are used due to the before mentioned lack of other available data. For both Singapore and Indonesia, the focus is on non-oil prices as well, since oil prices are quite volatile, have a large affect on price indices in these countries and have been trending downward over the period of this study. Further, for Singapore, the focus is on its domestic exports rather than its entrepot trade. Due to the inclusion of services and the problems that creates, NIPA data are largely ignored here. However, all data available are presented in the attached graphs and tables for purpose of comparison.

\section{Individual Country Results}

This section will analyze the movement of export and import prices country by country for the seven countries in this study, but will only touch briefly upon the Philippines. There is one general result that holds across all of these countries: both export and import prices throughout East Asia have fallen substantially throughout the crisis. Export prices in 1998 fell by a minimum of 3.3 percent in Hong Kong, and by a maximum of 19.2 percent in Korea. Import prices fell by even more in 1998, from a fall of 4.7 percent in Hong Kong to a fall of 33.4 percent in Indonesia (includes oil/gas). As Graphs 1 through 7 show, however, these price declines across the region began even before the crisis, for some of the countries starting as early as 1996. Following the events of 1997, though, the decline in trade prices intensified.

The behavior of volumes across these countries did differ, however. Several of the countries experienced export volume booms. Korea's official numbers indicate volume growth of 17.1 percent in 1998. If oil and gas are included, Indonesia's implied export volume growth was 26.8 percent (20.6 percent if oil and gas are excluded). Thailand (and likely the Philippines) also registered healthy growth in export volume. However, Taiwan saw a slight contraction or no growth in export volume in 1998, and Singapore and Hong Kong experienced a definite contraction in the volume of exports.

Here the effects of the devaluations become apparent. Almost uniformly, the countries with the largest nominal exchange rate depreciations had the highest growth of export volumes. Conversely, Hong Kong, which maintained its currency's fixed peg to the US dollar saw a contraction in export volume of 4.3 percent in 1998. Singapore, whose currency depreciated the least among the (now) flexible exchange rate countries, also had its real non-oil domestic exports fall by nearly one percent. Taiwan official export volume contracted by 1.5 percent in 1998 as its currency fell by 14.4 percent over the same period. In contrast, Korea with its devaluation of 32.9 percent in 1998 and Indonesia with a 71.2 percent devaluation had the highest export volume growth in the region. Thailand also had a relatively large devaluation and similarly registered strong export volume growth.

Import volumes around the region fell, with the curious exceptions of Indonesia and Taiwan, both of which had growth of 0.6 percent. Thailand saw the largest decline in import volumes with a fall of 27.2 percent. Korea's import volume in 1998 fell by nearly as much, falling 21.7 percent. Terms of trade may explain some of these results. Indonesia saw its terms of trade increase 9.9 percent in 1998 and Taiwan had the next best improvement in its terms, and increase of 4.8 percent. Conversely, Thailand had its terms of trade fall by 5.4 percent in 1998 . However, this is not 
universally true, as Korea's imports declined by a similar magnitude, yet Korea's terms of trade improved by 2.2 percent. However, the reader is reminded that the Indonesian data is subject to the caveats noted in Section II, which may complicate inference about changes in terms of trade.

Also of interest is the issue of import substitution: whether crisis countries have switched to importation of cheaper goods as their domestic demand has fallen. As mentioned in the section on data issues, when both price indices and unit value data are available, comparison of such series may reveal evidence of goods substitution. For both Korea and Taiwan both types of data are available. As noted previously, Korean import unit values did not fall by as much as Korean import prices in the first months of the crisis, suggesting that Korea was importing relatively expensive goods during that period. Starting in the Spring of 1998, however, Korea appears to have engaged in import substitution to cheaper goods, as import unit values fell by more than import prices. Taiwan, which is not a crisis country, had the exact opposite pattern. From mid-1997 through Spring of 1998 Taiwan's import unit values fell by more than their import prices, yet starting in the late Spring of 1998, their import unit values actually began to rise, while import prices fell moderately. This same pattern is exhibited in Taiwan's export unit values and prices. This would suggest that Taiwan began to both import and export relatively more expensive goods as the crisis lingered.

These results are summarized completely in Tables 1 through 7 at the end of this document. The NIPA results of the Philippines are also presented there; although, because of the inclusion of services the results are difficult to interpret. Nominal merchandise exports of the Philippines grew at a healthy rate in 1998, but are a bit slower than in previous years. If export prices of the Philippines fell in line with the other countries in the region, then it is likely that Philippine export volume may have grown more in 1998 than it did in previous years. This would be consistent with the results for the other countries examined above, given its relatively large devaluation of 28.9 percent in that year.

It is difficult to assess the global importance of these results on a country by country basis. The export revenue numbers for each country sum up the effect of the price declines on these countries individually. However, the next section aggregates these results across the six countries for which monthly data are available to quantify the effect of the regional crisis on global trade, with particular focus on trade with the United States.

\section{$\underline{\text { IV. Construction of Aggregate Indices for Asian Trade Prices and Volumes }}$}

This section presents aggregate trade indices for the six countries for which monthly trade price or volume data were available. The data from the previous section were chain linked by trade shares and by non-oil import shares of the United States to produce aggregate trade indices for the East Asian region. These indices give a measure of the regional and global impact of the tremendous fall in the region's export and import prices. The methodology used in the construction of these indices is presented below, and is followed by an analysis of their implications.

\section{Methodology: Construction of Trade Share Weighted Indices}

Using data from the previous section, monthly, trade-share weighted, aggregate indices were 
constructed for export revenue, prices and volumes, import payments, prices and volumes, and terms of trade for the region. The six countries included in the aggregate measures were: Hong Kong, Indonesia, Korea, Singapore, Taiwan and Thailand. Thailand was only included for the period 1996 through 1998, and hence, the annual percent change numbers for 1995 and 1996 in Table 8 exclude Thailand.

Monthly trade shares were constructed by summing each countries exports and imports for each month, and dividing by the sum of exports and imports for all six countries (or all five countries for the period in which Thailand is excluded). These trade shares were then used to weight each countries' relevant data on a month-by-month basis to create a chain-weighted, monthly, aggregate index for each category of data.

Non-oil exports were used in constructing Indonesia's trade shares, and similarly, non-oil exports and imports were used to build Singapore's trade shares. In the calculation of each index, non-oil data were used for Indonesia's export payments, volume and prices, and for Singapore's export and import trade data. In all cases, official prices and volumes were used where available, official unit values were used when price series were unavailable, and finally inferred series were used when they were the only data present. The exact series used are detailed in the data appendix.

\section{Methodology: Construction of Aggregate Export Price Index Weighted by US Import-Shares}

An aggregate index of export prices for the six countries named above was also calculated using US non-oil import-shares as weights. US non-oil imports from each country were taken from the Bureau of Economic Analysis of the US Department of Commerce. To construct each countries' monthly weight in the aggregate index, its monthly non-oil exports to the US were divided by the sum of non-oil exports from all six countries that month. As with the trade-share weighted indices, these monthly weights were then used to build a chain-weighted monthly series for export prices from these six countries. While the export price series from each country used in construction of the index are for total exports rather than exports to the United States, this should serve as a rough approximation for the effect of these countries exports on the United States.

\section{Aggregate Results}

The aggregated trade indices present a more complete picture of the effects of the crisis on East Asian trade, and through its associated prices and volumes, upon the world. These indices are shown in Graphs 8A-8C, and annual percent changes in the indices are presented in Table $8{ }^{1}$. The aggregate results show that trade prices in the region have been retreating since 1996, the year before

${ }^{1}$ In Table 8 and the discussion above, the reader may note that the reported percent changes in export revenues and import payments may not follow directly from the percent changes in the components. This is due to the fact that there may be compositional differences between the official price and volume indices used to calculate the aggregate indices, and thus the percent change in price summed with the percent change in volume may not necessarily equal the percent change in revenue/payment. 
the round of devaluations began. They also show that while export volumes continued to grow throughout the crisis (albeit at a slower rate), import volumes did decline in 1998. Further, the results appear to indicate that at least for the six countries used in constructing the aggregate indices, terms of trade were declining modestly in the years before the crisis, but have rose slightly in 1998. Data for the first two months of 1999 show that both export volumes and terms of trade have begun to deteriorate recently.

Export revenue for the six countries grew by 17.5 percent in 1995 in US dollar terms. During that same year, import payments grew even faster, at an 18.9 percent rate. However, growth of trade slowed dramatically in 1996, with exports growing by only 4.0 percent and the rate of import growth falling to 4.2 percent. 1997 had positive but slow growth for trade as well, but for the first time import growth fell below export growth, with export growth at 6.1 percent and import growth slowing to 4.6 percent. The full effects of the crisis became apparent in 1998, as export growth in US dollar terms fell by 3.6 percent, and imports plunged by 15.2 percent.

Much of the drop-off in trade growth is attributable to price effects, however. After growing by 5.5 percent in 1995, export prices for the region, as measured by the aggregate trade-share weighted index, began a steady decline that intensified following the devaluations of late 1997. Export prices for the region fell on average by 3.0 percent in 1996, by 4.8 percent in 1997 and by 9.1 percent in 1998. If US import shares are used as weights, the slide in export prices for these six countries was even steeper. Following a rise of 8.7 percent in 1995, export prices dropped by 6.3 percent, 9.5 percent and an amazing 16.6 percent in 1996, 1997 and 1998, respectively on an annual average basis. Aggregated import prices displayed a similar pattern. Following growth of 7.1 percent in 1995, import prices fell by 2.7 percent in 1996, dropped by a further 5.4 percent in 1997 , and dived by 10.8 percent in 1998, on average. These price declines have continued into 1999, with import prices in January and February falling 2.7 percent from the same period the year before, and export prices falling by 5.6 percent over the same period, or by 11.9 percent if US import shares are used as chain-weights.

The decline in the regions trade prices explains much of the fall in export revenue and import bills. The trade-share weighted volume indices paint a very different picture for exports than the US dollar denominated revenue figures. According to this constructed index, export growth did not seriously slow until 1998. In 1995 export volume for these six countries expanded by 12.0 percent. In the following two years, export volume grew by 6.6 and 8.8 percent, respectively. In 1998, growth was cut down to 0.7 percent, but was still positive. The first two months of 1999 have actually seen a decline in export volume from the year previous period.

The story for import volumes is more similar to the story of import payments for the region. Growth in import volume did slow in 1996, from the 1995 rate of 13.5 percent, to 6.0 percent. Import volume to the region ticked up by 7.5 percent in 1997. However, the region's import volume shrank by 9.6 percent in 1998, and by a further 10.7 percent in the first part of 1999 . The decline in import volume in 1998 was less severe than the drop in US dollar denominated imports, but was still quite severe.

Terms of trade for the region appears to have improved during the crisis, however. In 1997 
the region's terms of trade, as measured by the ratio of the aggregate export price index to the aggregate import price index (both weighted by trade shares), improved by 0.6 percent, and in 1998 grew by 1.9 percent. This followed declines of 1.5 percent and 0.3 percent in 1995 and 1996, respectively. The earlier falls in terms of trade may have played a contributing factor in the subsequent devaluations. What is more puzzling is the rise in terms of trade following the devaluations. As the next section will show, trade prices from Japan, Europe and the United States did not fall by as much as East Asia's in dollar terms. This would suggest that the terms of trade for the Asian region should have fallen. One possible answer is that export prices from the smaller, even less developed countries that are supplying these six countries with raw materials have fallen by even more. In particular, the decline in oil prices over this period may be a contributing factor to this result. Data from Singapore supports this hypothesis, as Table 5 illustrates: the general terms of trade remained mostly unchanged in 1998, but the non-oil terms of trade deteriorated during that period.

\section{Understanding the Fall in Export \& Import Prices}

The substantial export \& import price declines in the East Asian region presented in the previous two sections are slightly puzzling. According to the small, open economy model, these countries should not be able to influence the dollar denominated price they face in either export or import markets by devaluation; thus one should not observe the large declines that we do. If the country is a large enough source for the world supply of particular goods, it could theoretically affect the world price of its exports by devaluing and in essence shifting the world supply schedule out. If the country were a large enough demander of goods on the world market, it could also theoretically shift the world demand curve in with a devaluation, particularly if this was associated with a domestic recession. None of the countries in this study are that large in the world market, at least in terms of national income, hence their devaluations should have had little effect on their export or import prices under the small open economy model. However, the evidence of the previous sections seems to suggest otherwise.

The first question to be answered is whether or not the data are valid. As noted above, one might also be skeptical of data from Indonesia in general, and particularly data on wholesale prices, which may be contaminated by local cost factors. Unfortunately, we have no other sources of data for Indonesia, so we must rely on corroboration from other sources. Consultations with officials at both the Bank of Korea and the Bank of Thailand by the author suggest that at the very least their methods for calculating their price and volume indices are correct. Similar consultations with officials at the Bureau of Labor Statistics, suggest that there may be issues about the size of these two countries' sample baskets; however, there is little that can be done about that, and it is unlikely that both would have a downward bias in trend. The quality of data from Singapore, Hong Kong and Taiwan is likely as good or better than any other data from the region.

To validate the quality of these data, beyond inquiring about their construction, one can compare the trends in the data between countries, particularly with data from countries whose data construction is known to be of higher quality. It is clear from the various measures of import and export prices from the region presented in Graphs 1 through 7 that the trend in these prices has been downward, at least since the devaluation of the baht in July of 1997. Thus, the similar trend in the 
data across countries of the region tends to validate this trend within each country. While this adds some confidence to the general result, a comparison with US and Japanese data is even more helpful.

Graph 9A exhibits US import prices for goods originating from the Asian Newly Industrialized Economies (NIEs - Hong Kong, Korea, Singapore \& Taiwan), the European Union and the Japan from January 1996 through 1998. These data appear to validate the trend of East Asian trade prices, with import prices from the NIEs falling by more than 12 percent since the devaluation of the baht, through May 1999. Prices from Japan have fallen a much more modest five percent, while prices of imports from the EU have remained roughly constant over this period.

This is again confirmed by the two other graphs on that page, depicting Japanese import (Graph 9B) and export (Graph 9C) unit values by region of origin and destination (converted to US dollar denomination). Japanese export unit values to other Asia and import unit values from other Asia showed declines of 11.3 percent and 15.4 percent, respectively, from the devaluation of the baht to April 1999. Conversely, the corresponding data for trade with the United States and European Union exhibit less of a decline. These two additional sources of data in combination with the universal nature of declines in export and import prices from the East Asian data suggests that we can put some faith in the downward trend in East Asian dollar denominated trade prices, and that export prices from the region have fallen by a magnitude of between ten and twenty percent in 1998.

To a limited extent, we may also be able to infer that prices of Chinese and Malaysian exports and imports have fallen similarly. This is supported in part by the export and import prices of Singapore and Hong Kong, whose ports handle a significant share of the trade from Malaysia and China respectively.

The question then remains, why are the predictions of the small, open economy model contradicted by these data? There are at least five valid hypotheses that could explain the behavior of East Asian trade prices during the present crisis:

1) While individually, these countries may be small economies, collectively they are a major player in world trade. Hence, a regional recession combined with a large depreciation in regional currencies could affect US dollar denominated prices for broadly traded goods.

2) Barriers or costs to find new export markets which would violate the assumptions of the small, open economy model, combined with export destination, and import origination effects. If, for example, a large share of these countries' exports were to other crisis affected countries, and the cost of finding new export markets was sufficiently high, exporters in these countries might lower their prices to meet the new lower demand. Likewise, crisis affected countries may obtain lower import prices if a recession causes local demand to fall and the cost to the original exporter of finding new export markets was greater than the lost revenue in that market.

3) A large share of the trade conducted in this region is done by multinational corporations (MNCs), which likely have price setting power and may be price discriminating across national boundaries. To the extent that MNCs are granting price breaks to crisis economies 
to maintain market share, this would tend to drive import prices for these countries down.

4) The fall in both import and export prices reflects falling commodity prices, particularly oil prices.

5) The fall in both import and export prices reflects a decline in the prices of electronic components and semi-conductors, an industry with a large trade share in these economies.

Hypothesis (1) is supported by 1997 trade data from International Financial Statistics of the IMF. In that year developing Asia accounted for 18.4 percent of the world's total exports, and 18.1 percent of the world's total imports. Even if one looks at just the six countries that are used to construct the aggregate indices of Section IV, these countries represented 12.1 percent of world exports in 1997, and 12.0 percent of world imports. Hence, collectively these countries represent a large share of both world supply and demand.

Closely related to this idea is Hypothesis (2). Intra-regional trade forms a large portion of trade for all of the East Asian crisis countries. Table 9 illustrates the extent of the intra-regional component of total exports for each of these countries for the year 1998. The first column shows the percent of each countries exports going to the "Crisis-5" countries (Indonesia, Korea, Malaysia, Philippines and Thailand) plus Hong Kong, and the second column adds exports to Japan to the list. Hong Kong did not devalue its currency as the Crisis- 5 did, but it suffered a severe recession fighting a devaluation, and Japan has been mired in its worst recession in the post-war period. With the exception of Hong Kong, all of the countries examined here export between one-quarter and slightly more than one-third of their total exports to these contracting economies. Hong Kong, with only 9 percent of its exports directed to these faltering economies, is also the only country of those countries for which monthly data is available to not see a large decline in its export prices in 1998 (-3 percent versus -9 to -19 for the other countries).

There is support for Hypothesis (3) as well. According to the Survey of Current Business published by the US Bureau of Labor Statistics, intra-firm exports have accounted for approximately 35 percent of total US exports during the 1990's. Over that same period, intra-firm imports to the US accounted for more than 40 percent of US imports. Given the larger sum of Japanese foreign investment in East Asia, the corresponding numbers for Japanese intra-firm transfers may be even higher.

Hypotheses (4) and (5) may confuse cause and effect. Indeed, an important reason cited by many oil analysts for low global oil prices is the large drop in Asian demand for petroleum products since the crisis began. This is not to suggest that the devaluations alone are responsible for the decline in demand, but the regional recession that has coincided with them has significantly diminished the region's demand for petroleum. Likewise, many market analysts attribute the slump in electronic component prices to the glut in supply created by these same troubled Asian economies attempting to pursue export led recoveries from the recession. More generally, in specific industries, one of which being electronics and semiconductors, these nations are major global players, and as such should be able to affect world prices. 
Thus, while there is no clear answer to the question of what has lead to the dramatic decline in trade prices in East Asian economies, it is likely to be some combination of these hypotheses. Causes (1), (2) and (3) appear to be the more likely culprits behind the lower trade prices, and may also have contributed to the large decline in commodity and semiconductor prices globally.

\section{$\underline{\text { VI. Conclusions }}$}

Since 1996, export prices from the East Asia region have declined substantially, with this deterioration intensifying following the currency crisis in late-1997. The decline in export prices has greatly eroded export revenues for crisis countries, despite an increase in export volumes. While the volume of exports from the six countries that form the core of this study rose by 8.8 percent in 1997 and 0.7 percent in 1998, export revenues rose by only 6.1 percent in 1997 and declined by 3.6 percent in 1998. Price declines of 4.8 percent and 9.1 percent, respectively, were responsible for the fall in export revenues. Likewise, while imports by these countries did fall in 1998, the fall in volume of 9.6 percent was much less severe than the 15.2 percent drop in US dollar import payments which was due more to a 12.0 percent fall in import prices.

The implications of these trade price declines extend beyond East Asia. The United States economy has benefitted from the slump in Asian export prices. Import prices from the Asian newly industrialized economies (NIEs) have fallen by 12.4 percent since mid-1996, according to data from the Bureau of Labor Statistics. If the aggregate index for export prices from the six main countries in this study, chain-weighted by US import-shares is used, the decline in prices from 1996 to 1998 is an even more dramatic 24.5 percent. That would imply that US importers saved $\$ 35$ billion on the nominally valued $\$ 107.9$ billion that they imported from these countries from November 1997 through October 1998. In addition to its stimulative effects on the US economy, this savings has likely contributed to lower inflation rates in the United States. These savings are in addition to the indirect effect the Asian crisis has had on world commodity prices, particularly oil, as Asian demand for these goods collapsed. 


\section{Data Appendix}

\section{$\underline{\text { Hong Kong (HK) }}$}

1. Monthly average HK\$/US\$ exchange rate: from from Federal Reserve databases, average of NY noon rates.

2. Unit value of exports (official): in HK\$ from Hong Kong Census and Statistics Dept., converted to US\$ by dividing by (1).

3. Unit value of imports (official): in HK\$ from Hong Kong Census and Statistics Dept., converted to US\$ by dividing by (1).

4. Nominal exports: in US\$ from Hong Kong Census and Statistics Dept..

5. Nominal imports: in US\$ from Hong Kong Census and Statistics Dept..

6. Export volume (official): from Hong Kong Census and Statistics Dept., rebased to June 1997.

7. Import volume (official): from Hong Kong Census and Statistics Dept., rebased to June 1997.

8. NIPA nominal exports: in HK\$ from Hong Kong Census and Statistics Dept..

9. NIPA nominal imports: in HK\$ from Hong Kong Census and Statistics Dept..

10. NIPA real exports: from Hong Kong Census and Statistics Dept., rebased to June 1997.

11. NIPA real imports: from Hong Kong Census and Statistics Dept., rebased to June 1997.

12. Export volume (implied): (4) divided by (2).

13. Import volume (implied): (5) divided by (3).

14. $\quad$ Unit value of exports (implied): (4) divided by (6).

15. Unit value of imports (implied): (5) divided by (7).

16. NIPA export deflator: (8) divided by (10), divided by (1) to convert to US\$.

17. NIPA import deflator: (9) divided by (11), divided by (1) to convert to US\$.

\section{$\underline{\text { Indonesia (ID) }}$}

1. Monthly average rupiah/US\$ exchange rate: from from Federal Reserve databases, average of NY noon rates.

2. Wholesale price of exports: in rupiah from Central Bureau of Statistics, converted to US\$ by dividing by (1).

3. Wholesale price of non-oil/gas exports: in rupiah from Central Bureau of Statistics, converted to US $\$$ by dividing by (1).

4. Wholesale price of imports: in rupiah from Central Bureau of Statistics, converted to US\$ by dividing by (1).

5. Nominal exports: from Central Bureau of Statistics.

6. Nominal non-oil/gas exports: from Central Bureau of Statistics.

7. $\quad$ Nominal imports: from Central Bureau of Statistics.

8. $\quad$ NIPA nominal exports: in rupiah, from Central Bureau of Statistics.

9. NIPA nominal imports: in rupiah, from Central Bureau of Statistics.

10. NIPA real exports: in rupiah, from Central Bureau of Statistics, rebased to June 1997.

11. NIPA real imports: in rupiah, from Central Bureau of Statistics, rebased to June 1997. 
12. Export volume (implied by WPI): (5) divided by (2).

13. Non-oil/gas export volume (implied by WPI): (6) divided by (3).

14. Import volume (implied by WPI): (7) divided by (4).

15. NIPA export deflator: (8) divided by (10), converted to US\$ by dividing by (1).

16. NIPA import deflator: (9) divided by (11), converted to US\$ by dividing by (1).

\section{$\underline{\text { Japan (JA) }}$}

1. Monthly average yen/US\$ exchange rate: from from Federal Reserve databases, average of NY noon rates.

2. Export unit values, to Asia: in yen, from "The Summary Report on Trade of Japan" published by the Japan Tariff Association, converted to US\$ by dividing by (1).

3. Import unit values, from Asia: in yen, from "The Summary Report on Trade of Japan" published by the Japan Tariff Association, converted to US\$ by dividing by (1).

4. Export unit values, to EU: in yen, from "The Summary Report on Trade of Japan" published by the Japan Tariff Association, converted to US\$ by dividing by (1).

5. Import unit values, from EU: in yen, from "The Summary Report on Trade of Japan" published by the Japan Tariff Association, converted to US\$ by dividing by (1).

6. Export unit values, to US: in yen, from "The Summary Report on Trade of Japan" published by the Japan Tariff Association, converted to US\$ by dividing by (1).

7. Import unit values, from US: in yen, from "The Summary Report on Trade of Japan" published by the Japan Tariff Association, converted to US\$ by dividing by (1).

\section{$\underline{\text { Korea }(\mathrm{KO})}$}

1. Monthly average won/US\$ exchange rate: from from Federal Reserve databases, average of NY noon rates.

2. Export prices (official): in won, from Bank of Korea, converted to US\$ by dividing by (1).

3. Import prices (official): in won, from Bank of Korea, converted to US\$ by dividing by (1).

4. Nominal exports: from Bank of Korea.

5. Nominal imports: from Bank of Korea.

6. $\quad$ Export volume (official): from Bank of Korea, rebased to June 1997.

7. Import volume (official): from Bank of Korea, rebased to June 1997.

8. NIPA nominal exports: in won, from Bank of Korea.

9. NIPA nominal imports: in won, from Bank of Korea.

10. NIPA real exports: in won, from Bank of Korea, rebased to June 1997.

11. NIPA real imports: in won, from Bank of Korea, rebased to June 1997.

12. Export volume (implied): (4) divided by (2).

13. Import volume (implied): (5) divided by (3).

14. Export unit value (implied): (4) divided by (6).

15. Import unit value (implied): (5) divided by (7). 
16. NIPA export deflator: (8) divided by (10), converted to US\$ by dividing by (1).

17. NIPA import deflator: (9) divided by (11), converted to US\$ by dividing by (1).

\section{Philippines (PH)}

1. Monthly average peso/US\$ exchange rate: from from Federal Reserve databases, average of NY noon rates.

2. NIPA export deflator: in pesos, from Economic and Social Statistics Office, National Statistical Coordination Board, converted to US\$ by dividing by (1).

3. NIPA import deflator: in pesos, from Economic and Social Statistics Office, National Statistical Coordination Board, converted to US\$ by dividing by (1).

4. NIPA nominal exports: in pesos, from Economic and Social Statistics Office, National Statistical Coordination Board, converted to US\$ by dividing by (1).

5. NIPA nominal imports: in pesos, from Economic and Social Statistics Office, National Statistical Coordination Board, converted to US\$ by dividing by (1).

6. NIPA real exports: in pesos, from Economic and Social Statistics Office, National Statistical Coordination Board, rebased to June 1997.

7. NIPA real imports: in pesos, from Economic and Social Statistics Office, National Statistical Coordination Board, rebased to June 1997.

8. Nominal merchandise exports: from National Statistics Office.

9. Nominal merchandise imports: from National Statistics Office.

\section{$\underline{\text { Singapore (SI) }}$}

1. Monthly average $S \$ / U S \$$ exchange rate: from from Federal Reserve databases, average of NY noon rates.

2. Export price index, all items: in S\$, from Singapore Trade Development Board, converted to US\$ by dividing by (1).

3. Import price index, all items: in $\mathbf{S}$, from Singapore Trade Development Board, converted to US\$ by dividing by (1).

4. Nominal exports: in S\$, from Singapore Trade Development Board, converted to US\$ by dividing by (1).

5. Nominal domestic exports: in S\$, from Singapore Trade Development Board, converted to US\$ by dividing by (1).

6. Nominal non-oil exports: in S\$, from Singapore Trade Development Board, converted to US\$ by dividing by (1).

7. Nominal non-oil domestic exports: in S\$, from Singapore Trade Development Board C, converted to US\$ by dividing by (1).

8. Nominal imports: in S\$, from Singapore Trade Development Board, converted to US\$ by dividing by (1).

9. Nominal non-oil imports: in S\$, from Singapore Trade Development Board, converted to US\$ by dividing by (1).

10. Real exports: in 1990 S\$, from Singapore Trade Development Board, rebased to June 1997. 
11. Real domestic exports: in 1990 S\$, from Singapore Trade Development Board, rebased to June 1997.

12. Real non-oil exports: in 1990 S\$, from Singapore Trade Development Board, rebased to June 1997.

13. Real non-oil domestic exports: in 1990 S\$, from Singapore Trade Development Board, rebased to June 1997.

14. Real imports: in 1990 S\$, from Singapore Trade Development Board, rebased to June 1997.

15. Real non-oil imports: in 1990 S\$, from Singapore Trade Development Board, rebased to June 1997.

16. Non-oil export prices: implied by (6) divided by (12), converted to US\$ by dividing by (1).

17. Non-oil domestic export prices: implied by (7) divided by (13), converted to US\$ by dividing by (1).

18. Non-oil import prices: implied by (9) divided by (15), converted to US\$ by dividing by (1).

\section{$\underline{\text { Taiwan (TA) }}$}

1. Monthly average NTD/US\$ exchange rate: from Federal Reserve databases, average of NY noon rates.

2. Export price index (official): in NTD, from Taiwan Ministry of Finance, Dept. of Statistics, converted to US\$ by dividing by (1).

3. Import price index (official): in NTD, from Taiwan Ministry of Finance, Dept. of Statistics, converted to US\$ by dividing by (1).

4. Nominal exports: from Taiwan Ministry of Finance, Dept. of Statistics.

5. Nominal imports: from Taiwan Ministry of Finance, Dept. of Statistics.

6. Export unit value index (official): in NTD, from Taiwan Ministry of Finance, Dept. of Statistics, converted to US\$ by dividing by (1).

7. Import unit value index (official): in NTD, from Taiwan Ministry of Finance, Dept. of Statistics, converted to US\$ by dividing by (1).

8. Export quantum index (official): from Taiwan Ministry of Finance, Dept. of Statistics.

9. Import quantum index (official): from Taiwan Ministry of Finance, Dept. of Statistics.

10. NIPA nominal exports: in NTD, from Taiwan Directorate-General of Budget, Accounting and Statistics, converted to US\$ by dividing by (1).

11. NIPA nominal imports: in NTD, from Taiwan Directorate-General of Budget, Accounting and Statistics, converted to US\$ by dividing by (1).

12. NIPA real exports: in NTD, from Taiwan Directorate-General of Budget, Accounting and Statistics, rebased to June 1997.

13. NIPA real imports: in NTD, from Taiwan Directorate-General of Budget, Accounting and Statistics, rebased to June 1997.

14. Export volume (implied): (4) divided by (2).

15. Export volume (implied): (5) divided by (3).

16. NIPA export deflator: (10) divided by (12), converted to US\$ by dividing by (1). 
17. NIPA import deflator: (11) divided by (13), converted to US $\$$ by dividing by (1).

Thailand (TH)

1. $\quad$ Export unit value index (official): in US\$, from Bank of Thailand.

2. Import unit value index (official): in US\$, from Bank of Thailand.

3. Nominal exports: from Customs Department.

4. Nominal imports: from Customs Department.

5. Export volume index (official): from Bank of Thailand.

6. Import volume index (official): from Bank of Thailand.

7. $\quad$ Export volume index (implied): (3) divided by (1).

8. $\quad$ Import volume index (implied): (4) divided by (2).

9. $\quad$ Export unit value index (implied): (3) divided by (5).

10. Import unit value index (implied): (4) divided by (6).

\section{$\underline{\text { United States (US) }}$}

1. US import prices from EU11: from the Bureau of Labor Statistics, United States Department of Labor.

2. US import prices from Japan: from the Bureau of Labor Statistics, United States Department of Labor.

3. US import prices from NIE's: from the Bureau of Labor Statistics, United States Department of Labor.

4. US non-oil imports, total: from the Bureau of Economic Analysis, United States Department of Commerce.

5. US non-oil imports, from Hong Kong: from the Bureau of Economic Analysis, United States Department of Commerce.

6. US non-oil imports, from Indonesia: from the Bureau of Economic Analysis, United States Department of Commerce.

7. US non-oil imports, from S. Korea: from the Bureau of Economic Analysis, United States Department of Commerce.

8. US non-oil imports, from Singapore: from the Bureau of Economic Analysis, United States Department of Commerce.

9. US non-oil imports, from Taiwan: from the Bureau of Economic Analysis, United States Department of Commerce.

10. US non-oil imports, from Thailand: from the Bureau of Economic Analysis, United States Department of Commerce.

11. Share of US non-oil imports from Hong Kong: (5) divided by (4).

12. Share of US non-oil imports from Indonesia: (6) divided by (4).

13. Share of US non-oil imports from S. Korea: (7) divided by (4).

14. Share of US non-oil imports from Singapore: (8) divided by (4).

15. Share of US non-oil imports from Taiwan: (9) divided by (4).

16. Share of US non-oil imports from Thailand: (10) divided by (4). 


\section{$\underline{\text { Aggregated Data }}$}

The aggregated six country export and import price and volume indices and aggregated export revenues and import bills were constructed from the data of Hong Kong, Indonesia, Korea, Singapore, Taiwan and Thailand. Non-oil export data was used for Indonesia, and non-oil domestic export and non-oil import data were used for Singapore. Aggregated indices do not include Thailand for 1995, due to lack of data. Trade share weighted indices were constructed using monthly trade share as chain weights. Monthly trade share was computed as the sum of an individual country's monthly merchandise exports and imports as a proportion of the sum of all six countries' monthly exports and imports. Merchandise export and import data used are: HK(4), HK(5), ID(6), ID(7), KO(4), KO(5), SI(7), SI(9), TA(4), TA(5), TH(3), and TH(4). The aggregated export price index weighted by US non-oil import shares was constructed using the non-oil import share of each of the six countries as chain weights. The corresponding import shares used are: US(11), US(12), US(13), US(14), US(15), US(16). Individual country export prices used in the construction of these indices are: $\mathrm{HK}(2), \operatorname{ID}(3), \mathrm{KO}(2), \operatorname{SI}(17), \mathrm{TA}(2), \mathrm{TH}(1)$. Individual country import prices used in the construction of these indices are: $\operatorname{HK}(3), \operatorname{ID}(4)$, $\mathrm{KO}(3), \mathrm{SI}(18), \mathrm{TA}(3), \mathrm{TH}(2)$. Individual country export volumes used in the construction of these indices are: $\mathrm{HK}(6), \mathrm{ID}(13), \mathrm{KO}(6), \mathrm{SI}(13), \mathrm{TA}(8), \mathrm{TH}(5)$. Individual country export volumes used in the construction of these indices are: $\mathrm{HK}(7), \operatorname{ID}(14), \mathrm{KO}(7), \operatorname{SI}(15), \mathrm{TA}(9)$, $\mathrm{TH}(6)$. 
Table 1: Hong Kong

\begin{tabular}{|l|c|c|c|c|c|}
\hline Percent Change, Yr/Yr & $\mathbf{1 9 9 5}$ & $\mathbf{1 9 9 6}$ & $\mathbf{1 9 9 7}$ & $\mathbf{1 9 9 8}$ & $\mathbf{1 9 9 9 *}$ \\
\hline Nominal Exchange Rate & -0.09 & 0.02 & -0.11 & -0.05 & -0.07 \\
\hline Terms of Trade & -1.69 & 1.01 & 0.72 & 1.23 & -0.68 \\
\hline Nominal Exports & 14.77 & 4.02 & 4.06 & -7.47 & -9.04 \\
\hline Export Volume & & & & & \\
\hline \multicolumn{1}{|c|}{ 1) Official } & 12.00 & 4.78 & 6.14 & -4.30 & -4.78 \\
\hline 2) Implied & 11.23 & 4.34 & 5.89 & -3.81 & -4.89 \\
\hline 3) NIPA Real Exports & 10.96 & 5.45 & 5.12 & -4.62 & N/A \\
\hline Export Prices & & & & & \\
\hline 1) Implied & 3.20 & -0.22 & -1.72 & -3.76 & -4.38 \\
\hline 2) Official & 2.49 & -0.65 & -1.96 & -3.30 & -4.40 \\
\hline 3) NIPA Implicit Export Prices & 2.75 & -0.14 & -1.71 & -3.55 & N/A \\
\hline Nominal Imports & 19.16 & 3.00 & 5.07 & -11.51 & -13.89 \\
\hline Import Volume & & & & & \\
\hline 1) Official & 13.74 & 4.33 & 7.20 & -7.12 & -10.24 \\
\hline 2) Implied & 13.59 & 4.39 & 7.67 & -6.93 & -10.57 \\
\hline 3) NIPA Real Imports & 12.67 & 4.36 & 6.88 & -6.62 & N/A \\
\hline Import Prices & & & & & \\
\hline 1) Implied & 4.96 & -1.22 & -2.43 & -4.94 & -3.72 \\
\hline 2) Official & 4.81 & -1.19 & -1.99 & -4.72 & -4.04 \\
\hline 3) NIPA Implicit Import Prices & 5.09 & -0.95 & -1.71 & -4.33 & N/A \\
\hline
\end{tabular}

*Through March.

Table 2: Indonesia

\begin{tabular}{|l|c|c|c|c|c|}
\hline Percent Change, Yr/Yr & $\mathbf{1 9 9 5}$ & $\mathbf{1 9 9 6}$ & $\mathbf{1 9 9 7}$ & $\mathbf{1 9 9 8}$ & $\mathbf{1 9 9 9 *}$ \\
\hline Nominal Exchange Rate & -3.90 & -4.01 & -15.54 & -71.20 & 7.38 \\
\hline Terms of Trade & 5.69 & 8.32 & 8.26 & 9.90 & -31.06 \\
\hline Nominal Exports & 13.39 & 9.68 & 7.28 & -8.60 & -19.01 \\
\hline Non-Oil Exports & 15.13 & 8.98 & 9.79 & -1.81 & -19.28 \\
\hline Export Volume & & & & & \\
\hline \multicolumn{1}{|c|}{ 1) Implied (WPI) } & 4.70 & -0.13 & 13.40 & 26.83 & -13.73 \\
\hline 2) Non-Oil Implied (WPI) & 2.60 & 10.77 & 17.51 & 20.57 & -19.26 \\
\hline 3) NIPA Real Exports & N/A & N/A & 7.80 & 10.64 & -53.45 \\
\hline Export Prices & & & & & \\
\hline \multicolumn{1}{|c|}{ 1) Wholesale Export Prices } & 8.69 & 9.60 & -4.63 & -28.16 & -6.82 \\
\hline 2) Non-Oil Wholesale Exp. Prs. & 12.46 & -1.44 & -6.39 & -18.50 & -0.44 \\
\hline 3) NIPA Implicit Export Prices & N/A & N/A & -4.24 & -22.30 & 49.73 \\
\hline Nominal Imports & 27.03 & 5.66 & -2.91 & -34.41 & -23.37 \\
\hline Import Volume & & & & & \\
\hline 1) Implied (WPI) & 23.41 & 4.51 & 10.30 & 0.57 & -43.67 \\
\hline 2) NIPA Real Imports & N/A & N/A & 14.72 & -5.37 & -52.41 \\
\hline Import Prices & & & & & \\
\hline 1) Wholesale Import Prices & 2.86 & 1.15 & -10.59 & -33.44 & 34.31 \\
\hline 2) NIPA Implicit Import Prices & N/A & N/A & -9.69 & -23.61 & 63.80 \\
\hline
\end{tabular}

*Through March. 
Table 3: Korea

\begin{tabular}{|l|c|c|c|c|c|}
\hline Percent Change, Yr/Yr & $\mathbf{1 9 9 5}$ & $\mathbf{1 9 9 6}$ & $\mathbf{1 9 9 7}$ & $\mathbf{1 9 9 8}$ & $\mathbf{1 9 9 9}$ \\
\hline Nominal Exchange Rate & 4.41 & -3.95 & -13.84 & -32.92 & 33.89 \\
\hline Terms of Trade & -4.19 & -4.83 & -2.75 & 2.19 & -6.60 \\
\hline Nominal Exports & 31.88 & 4.33 & 7.54 & -4.91 & -3.11 \\
\hline Export Volume & & & & & \\
\hline 1) Official & 24.06 & 20.00 & 24.89 & 17.13 & N/A \\
\hline 2) Implied & 24.79 & 13.66 & 18.96 & 7.31 & 7.83 \\
\hline 3) NIPA Real Exports & 24.60 & 11.21 & 21.44 & 13.32 & 12.43 \\
\hline Export Prices & & & & & \\
\hline \multicolumn{1}{|c|}{ Implied } & 5.83 & -7.96 & -9.28 & -11.84 & -10.00 \\
\hline 2) Official & 6.45 & -12.18 & -13.93 & -19.23 & N/A \\
\hline 3) NIPA Implicit Export Prices & 6.28 & -6.37 & -11.61 & -16.29 & N/A \\
\hline Nominal Imports & 32.32 & 12.11 & -1.21 & -36.08 & 6.61 \\
\hline Import Volume & & & & & \\
\hline 1) Official & 21.20 & 12.72 & 1.49 & -21.65 & N/A \\
\hline 2) Implied & 20.10 & 16.02 & 5.90 & -25.94 & 10.72 \\
\hline 3) NIPA Real Imports & 22.36 & 14.25 & 3.18 & -22.01 & 27.48 \\
\hline Import Prices & & & & & \\
\hline 1) Implied & 10.39 & -3.32 & -6.64 & -13.79 & -3.65 \\
\hline 2) Official & 9.25 & -0.40 & -2.64 & -18.21 & N/A \\
\hline 3) NIPA Implicit Import Prices & 9.02 & -1.19 & -5.25 & -13.40 & N/A \\
\hline
\end{tabular}

*Through March.

Table 4: Philippines

\begin{tabular}{|l|c|c|c|c|c|}
\hline Percent Change, Q3/Q3 & $\mathbf{1 9 9 5}$ & $\mathbf{1 9 9 6}$ & $\mathbf{1 9 9 7}$ & $\mathbf{1 9 9 8}$ & $\mathbf{1 9 9 9 *}$ \\
\hline Nominal Exchange Rate & 2.55 & -1.93 & -9.74 & -28.89 & 5.52 \\
\hline Terms of Trade & 1.24 & 1.00 & -2.97 & 13.71 & 6.93 \\
\hline NIPA Nominal Exports & 23.66 & 24.69 & 20.38 & -10.53 & -1.76 \\
\hline Nominal Merchandise Exports & 29.29 & 18.27 & 22.80 & 16.93 & 15.19 \\
\hline Export Volume & & & & & \\
\hline \multicolumn{1}{|c|}{ 1) NIPA Real Exports } & 12.04 & 15.40 & 17.15 & -14.33 & -17.75 \\
\hline Export Prices & & & & & \\
\hline \multicolumn{1}{|c|}{ 1) NIPA Implicit Export Prices } & 10.48 & 8.02 & 2.52 & 5.25 & 19.44 \\
\hline NIPA Nominal Imports & 26.88 & 24.87 & 19.17 & -20.65 & -11.80 \\
\hline Nominal Merchandise Imports & 24.71 & 22.47 & 10.22 & -17.02 & -9.11 \\
\hline Import Volume & & & & & \\
\hline \multicolumn{1}{|c|}{ 1) NIPA Real Imports } & 16.02 & 16.74 & 13.49 & -14.35 & -21.04 \\
\hline Import Prices & & & & & \\
\hline \multicolumn{1}{|c|}{ 1) NIPA Implicit Import Prices } & 9.13 & 7.05 & 5.41 & -7.15 & 11.70 \\
\hline
\end{tabular}

*Through Q1. 
Table 5: Singapore

\begin{tabular}{|l|c|c|c|c|c|}
\hline Percent Change, Yr/Yr & $\mathbf{1 9 9 5}$ & $\mathbf{1 9 9 6}$ & $\mathbf{1 9 9 7}$ & $\mathbf{1 9 9 8}$ & $\mathbf{1 9 9 9} *$ \\
\hline Nominal Exchange Rate & 7.67 & 0.53 & -4.88 & -11.28 & -3.09 \\
\hline Terms of Trade, All Trade & -1.67 & 0.24 & -0.01 & -0.01 & -1.45 \\
\hline Terms of Trade, Non-Oil Domestic & -2.20 & -0.92 & 1.20 & -0.16 & -1.44 \\
\hline Nominal Non-Oil Domestic Exports & 22.13 & 3.19 & -0.18 & -10.20 & -3.56 \\
\hline Export Volume & & & & & \\
\hline 1) Real Exports & 16.06 & 7.29 & 6.78 & -0.69 & -2.31 \\
\hline 2) Real Non-Oil Exports & 18.44 & 7.67 & 7.67 & -1.33 & -3.11 \\
\hline 3) Real Non-Oil Domestic Exports & 18.03 & 6.87 & 6.18 & -0.89 & 2.49 \\
\hline Export Prices & & & & & \\
\hline 1) Exports & 5.81 & -0.40 & -6.34 & -12.95 & -6.78 \\
\hline 2) Non-Oil Exports (Implied) & 4.79 & -3.06 & -6.33 & -9.60 & -5.49 \\
\hline 3) Non-Oil Domestic Exports (Implied) & 3.65 & -3.40 & -5.84 & -9.54 & -5.81 \\
\hline Nominal Non-Oil Imports & 22.26 & 4.03 & 0.59 & -21.92 & -8.53 \\
\hline Import Volume & & & & & \\
\hline 1) Real Imports & 13.77 & 7.06 & 8.10 & -12.54 & -3.60 \\
\hline 2) Real Non-Oil Imports & 15.51 & 6.79 & 8.26 & -14.00 & -4.07 \\
\hline Import Prices & & & & & -4.42 \\
\hline 1) Imports & 7.58 & -0.65 & -6.34 & -12.92 & -4.47 \\
\hline 2) Non-Oil Imports (Implied) & 5.96 & -2.51 & -6.95 & -9.38 & -4.47 \\
\hline
\end{tabular}

*Through April.

Table 6: Taiwan

\begin{tabular}{|l|c|c|c|c|c|}
\hline Percent Change, Yr/Yr & $\mathbf{1 9 9 5}$ & $\mathbf{1 9 9 6}$ & $\mathbf{1 9 9 7}$ & $\mathbf{1 9 9 8}$ & $\mathbf{1 9 9 9 *}$ \\
\hline Nominal Exchange Rate & -0.09 & -3.60 & -4.30 & -14.36 & 1.38 \\
\hline Terms of Trade & -3.03 & 4.28 & 3.45 & 4.83 & -2.10 \\
\hline Nominal Exports & 20.23 & 3.59 & 5.29 & -9.27 & 4.84 \\
\hline Export Volume & & & & & \\
\hline 1) Implied from Price Index & 12.69 & 5.71 & 8.10 & 0.33 & 15.54 \\
\hline 2) Official & 5.01 & 5.80 & 6.96 & -1.54 & 7.58 \\
\hline 3) NIPA Real Exports & 12.79 & 7.07 & 8.67 & 2.83 & 9.76 \\
\hline Export Prices & & & & & \\
\hline 1) Official Price Index & 6.73 & -1.91 & -2.58 & -9.41 & -9.30 \\
\hline 2) Unit Value & 13.44 & -0.95 & -2.22 & -7.46 & -0.08 \\
\hline 3) NIPA Implicit Export Prices & 5.85 & -2.60 & -3.27 & -10.65 & -6.76 \\
\hline Nominal Imports & 21.41 & -2.40 & 13.15 & -8.46 & -5.60 \\
\hline Import Volume & & & & & \\
\hline 1) Implied from Price Index & 10.28 & 3.92 & 20.26 & 5.92 & 1.78 \\
\hline 2) Official & 8.31 & 1.87 & 17.60 & 0.59 & -6.18 \\
\hline 3) NIPA Real Imports & 9.83 & 5.10 & 13.36 & 5.51 & 2.33 \\
\hline Import Prices & & & & & -7.37 \\
\hline 1) Official Price Index & 10.03 & -5.97 & -5.84 & -13.59 & -6.16 \\
\hline 2) Unit Value & 11.84 & -2.78 & -5.62 & -8.57 & 1.08 \\
\hline 3) NIPA Implicit Import Prices & 9.05 & -4.81 & -4.88 & -11.61 & -6 \\
\hline
\end{tabular}

*Through February for monthly data on official volumes and unit values, through May for official prices, nominal trade and implied volumes, and through Q1 for NIPA data. 
Table 7: Thailand

\begin{tabular}{|l|c|c|c|c|c|}
\hline Percent Change, Yr/Yr & $\mathbf{1 9 9 5}$ & $\mathbf{1 9 9 6}$ & $\mathbf{1 9 9 7}$ & $\mathbf{1 9 9 8}$ & $\mathbf{1 9 9 9 *}$ \\
\hline Nominal Exchange Rate & N/A & N/A & -15.27 & -26.86 & 33.52 \\
\hline Terms of Trade & N/A & N/A & 0.01 & -5.44 & 5.06 \\
\hline Nominal Merchandise Exports & N/A & N/A & 3.07 & -5.15 & -7.08 \\
\hline Export Volume & & & & & \\
\hline 1) Implied from Unit Value & N/A & N/A & 6.84 & 9.84 & -4.15 \\
\hline 2) Official & N/A & N/A & 7.61 & 7.90 & -3.80 \\
\hline Export Prices & & & & & \\
\hline 1) Official Unit Value & N/A & N/A & -3.33 & -13.79 & -3.12 \\
\hline 2) Implied from Unit Value & N/A & N/A & -3.89 & -12.39 & -3.27 \\
\hline Nominal Merchandise Imports & N/A & N/A & -13.11 & -31.64 & 3.48 \\
\hline Import Volume & & & & & \\
\hline 1) Implied from Unit Value & N/A & N/A & -10.35 & -24.84 & 12.25 \\
\hline 2) Official & N/A & N/A & -10.61 & -27.16 & 4.91 \\
\hline Import Prices & & & & & \\
\hline 1) Official Unit Value & N/A & N/A & -3.34 & -8.77 & -7.78 \\
\hline 2) Implied from Unit Value & N/A & N/A & -2.87 & -6.00 & -1.52 \\
\hline
\end{tabular}

*Through February.

Table 8: Aggregated Results*

\begin{tabular}{|l|c|c|c|c|c|}
\hline Percent Change, Yr/Yr & $\mathbf{1 9 9 5}$ & $\mathbf{1 9 9 6}$ & $\mathbf{1 9 9 7}$ & $\mathbf{1 9 9 8}$ & $\mathbf{1 9 9 9 *}$ \\
\hline Terms of Trade & -1.50 & -0.27 & 0.59 & 1.86 & -2.90 \\
\hline Export Revenue & 17.47 & 3.95 & 6.06 & -3.64 & -7.37 \\
\hline Export Volume & & & & & \\
\hline 1) Weighted by Trade Share & 11.96 & 6.60 & 8.76 & 0.65 & -4.18 \\
\hline Export Prices & & & & & \\
\hline 1) Weighted by Trade Share & 5.47 & -2.99 & -4.83 & -9.08 & -5.56 \\
\hline 2) Weighted by US Import Share & 8.71 & -6.33 & -9.52 & -16.57 & -11.94 \\
\hline Import Payments & 18.87 & 4.19 & 4.61 & -15.21 & -9.90 \\
\hline Import Volume & & & & & \\
\hline 1) Weighted by Trade Share & 13.47 & 5.96 & 7.52 & -9.56 & -10.65 \\
\hline Import Prices & & & & & -2.74 \\
\hline \multicolumn{1}{|l|}{ 1) Weighted by Trade Share } & 7.06 & -2.73 & -5.36 & -10.76 & -1 \\
\hline Share of US Imports 1998: & & $\mathbf{1 2 . 5}$ percent \\
Value of US Imports 1998: \\
Value of US 1998 at 1996 prices:
\end{tabular}

*Hong Kong, Indonesia (Non-oil), Korea, Singapore (Non-oil emports and ixports),

Taiwan, and Thailand (1997-1998); through February in 1999. 
Table 9: Trade Shares of Exports with Crisis Countries

\begin{tabular}{|l|c|c|c|}
\hline Trade Share with: & Crisis-5 + H.K. & Crisis-5 + H.K. + Japan & 1998 Chg. in Export Price \\
\hline Hong Kong & 3.9 & 9.2 & -3.3 \\
\hline Indonesia & 15.2 & 33.9 & -18.5 \\
\hline Korea & 14.3 & 23.5 & -19.2 \\
\hline Philippines & 12.5 & 26.8 & -20.7 \\
\hline Singapore & 32 & 38.6 & -9.5 \\
\hline Taiwan & 30.3 & 38.7 & -9.4 \\
\hline Thailand & 12.7 & 26.5 & -13.8 \\
\hline
\end{tabular}



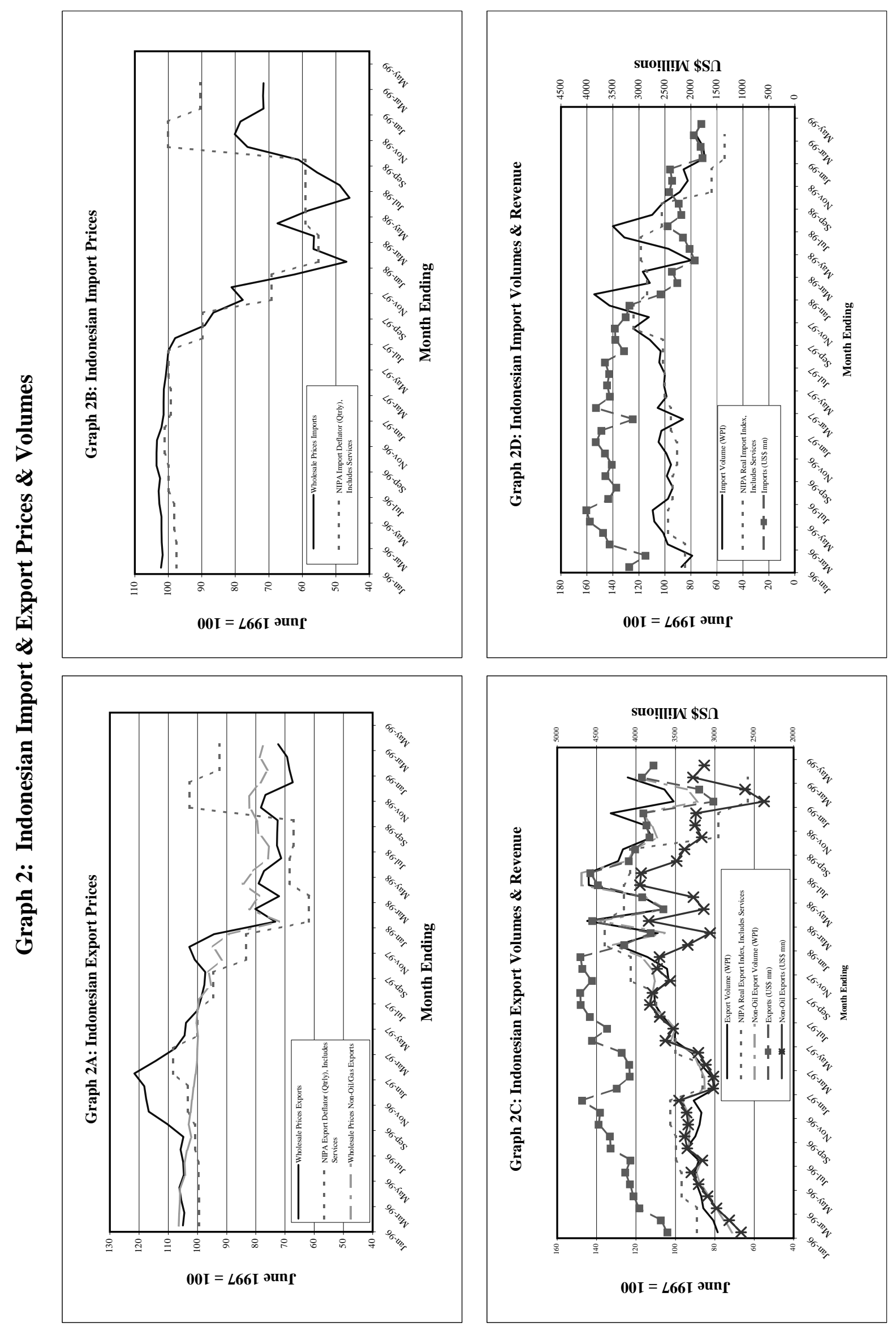

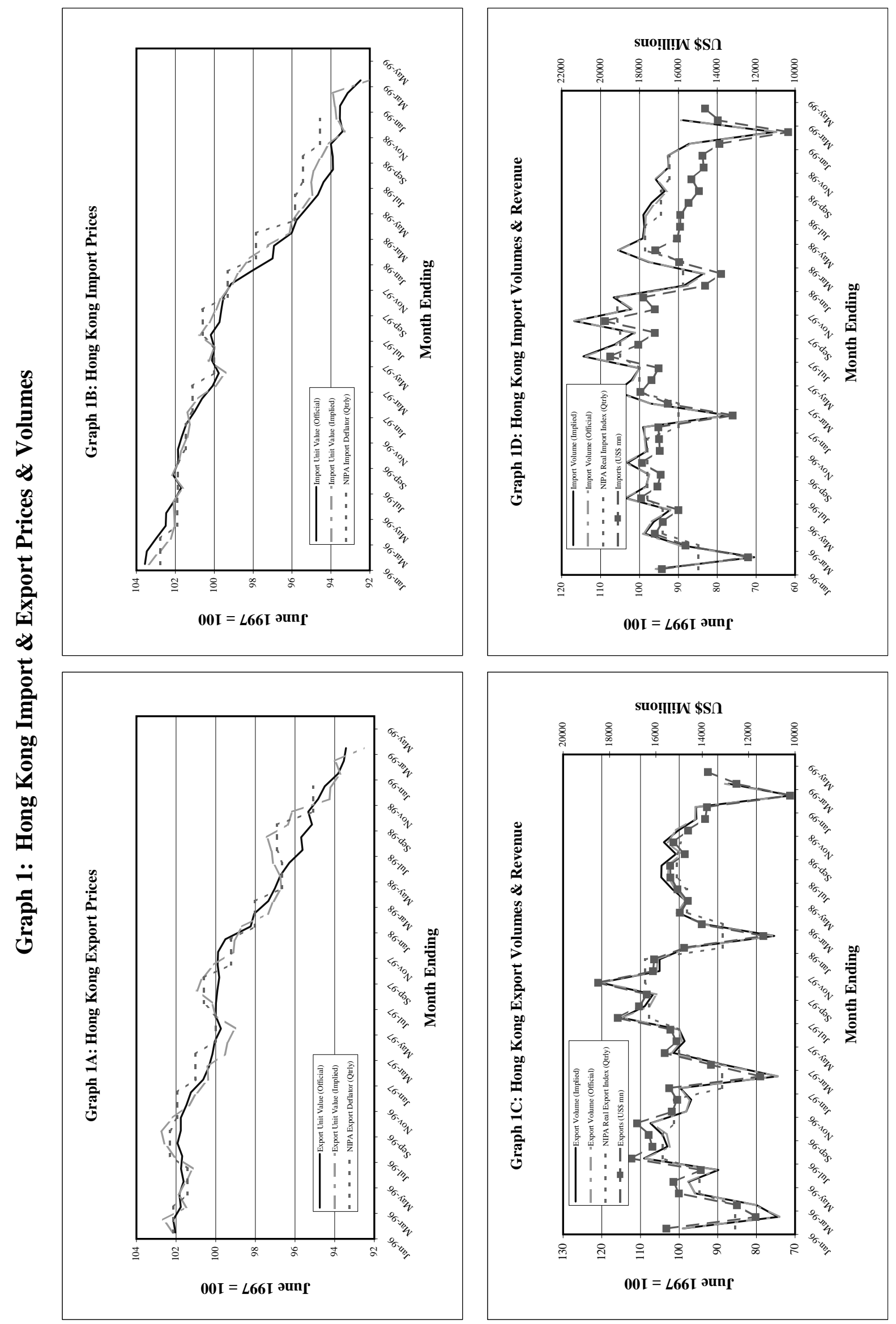

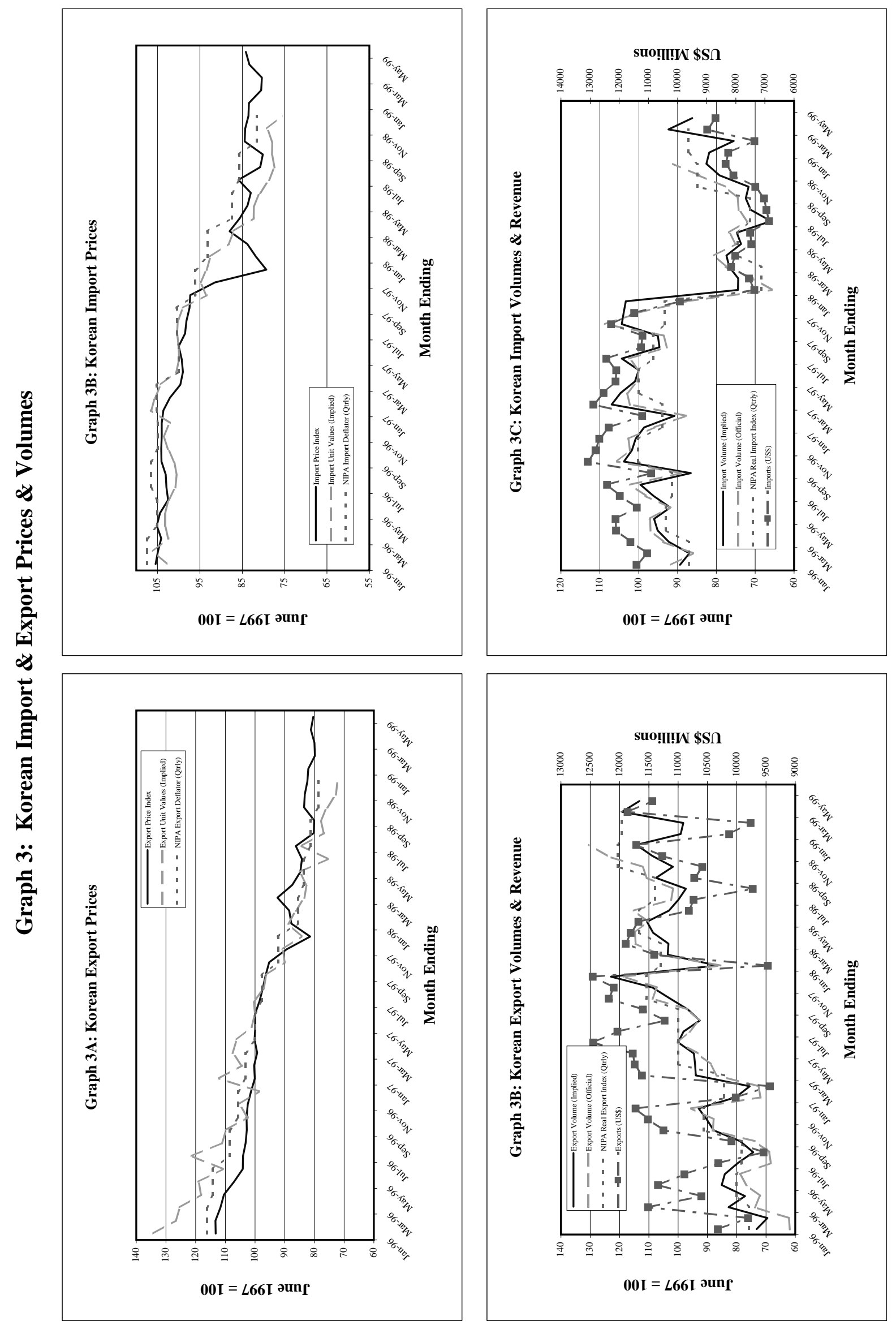

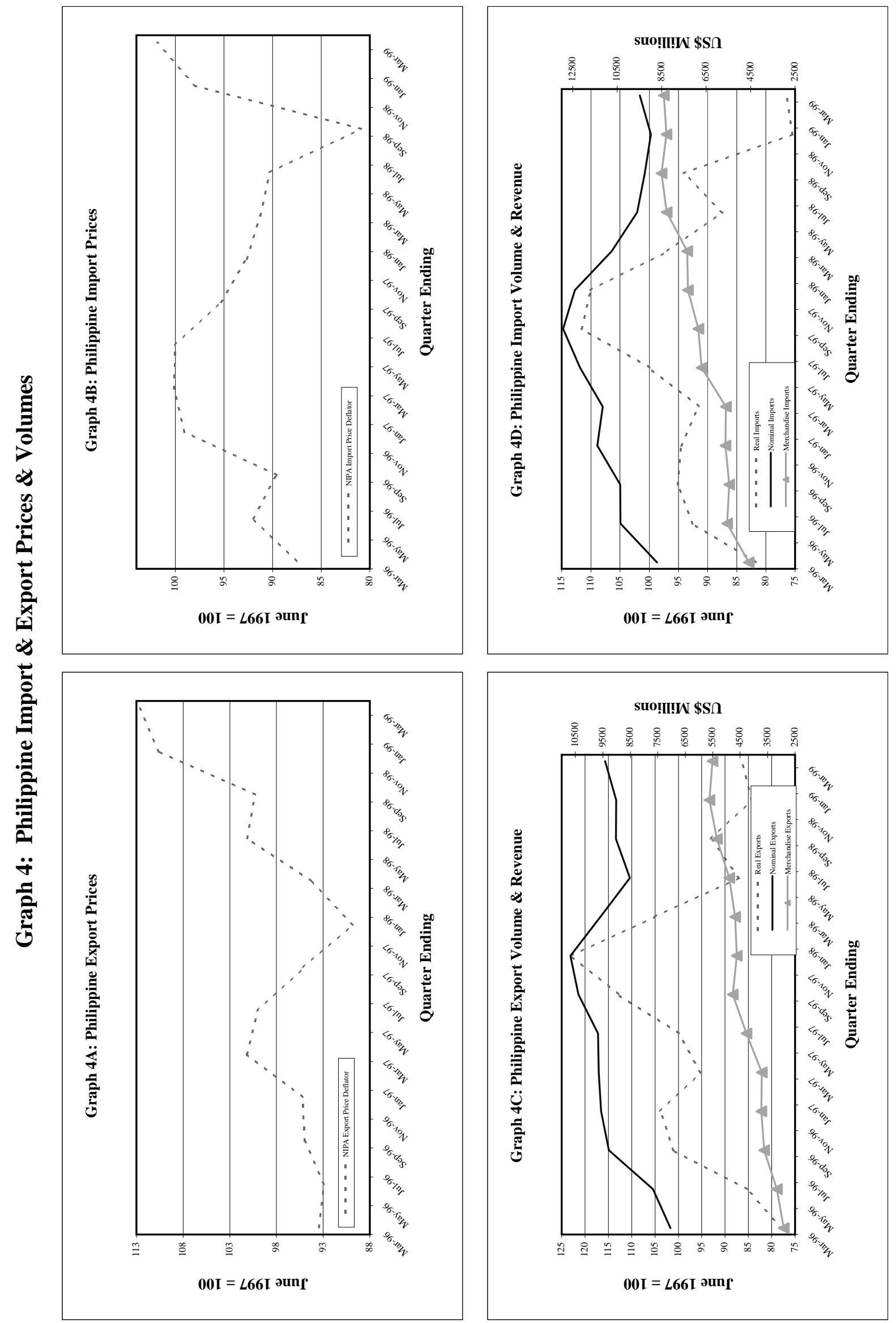

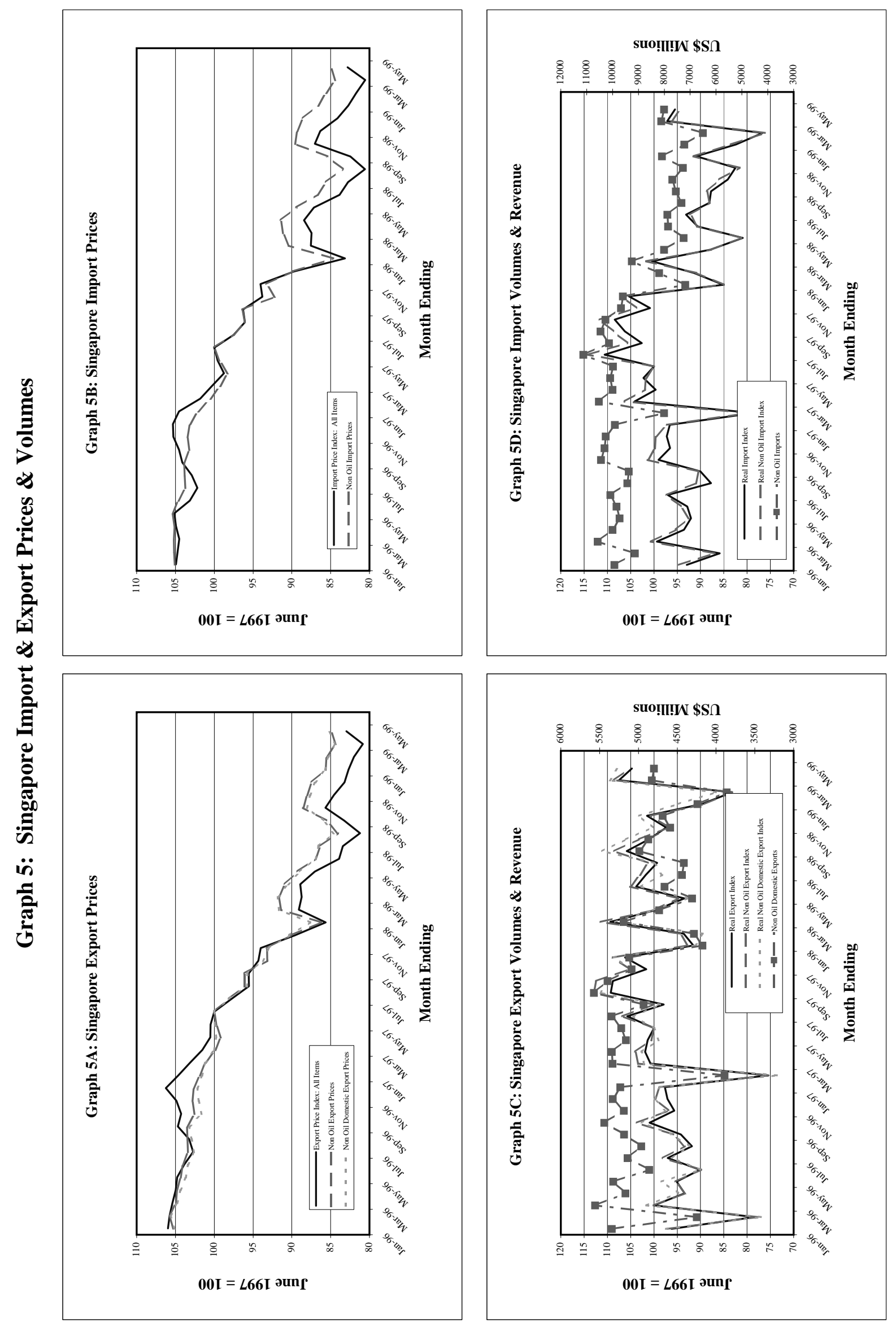

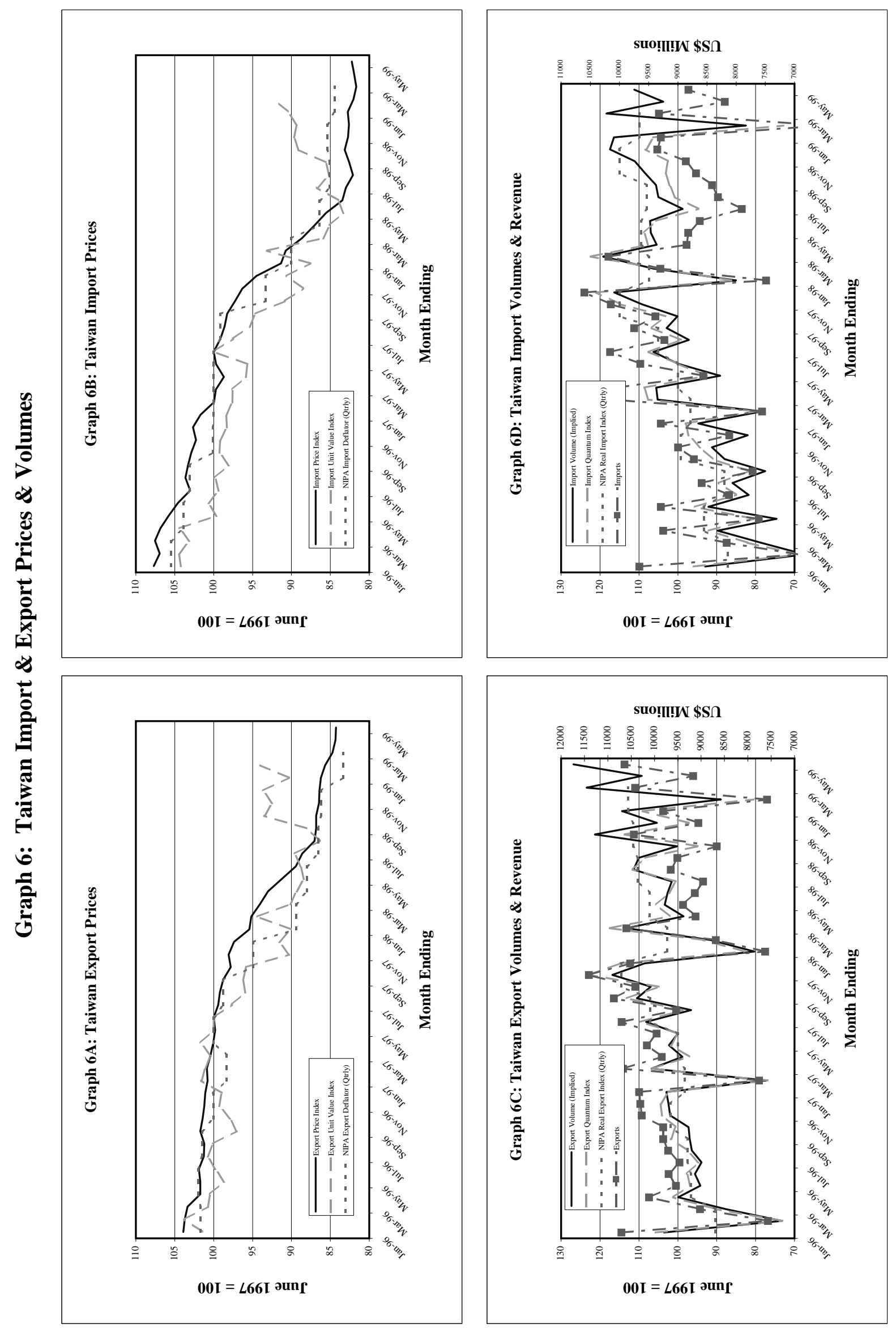

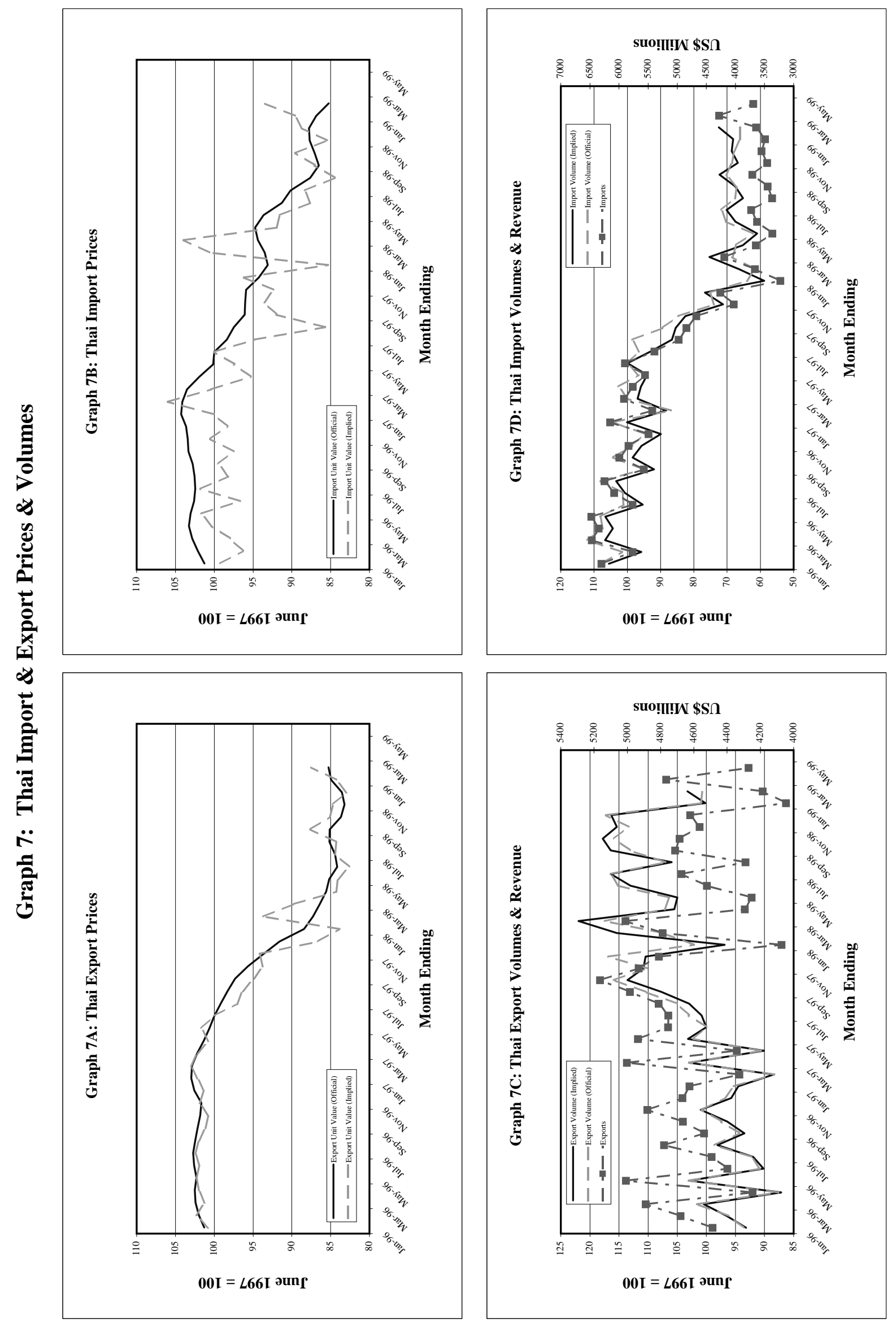

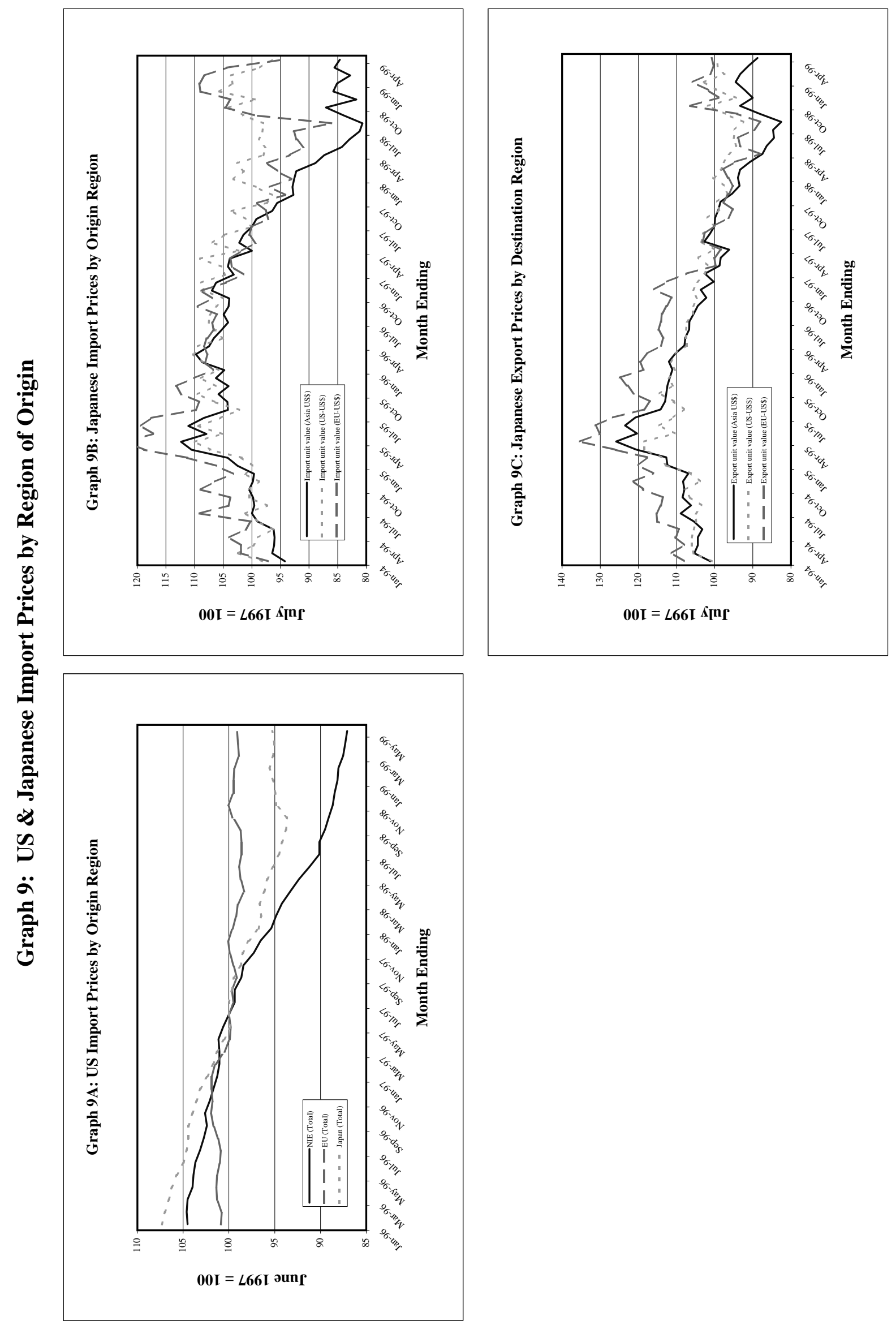

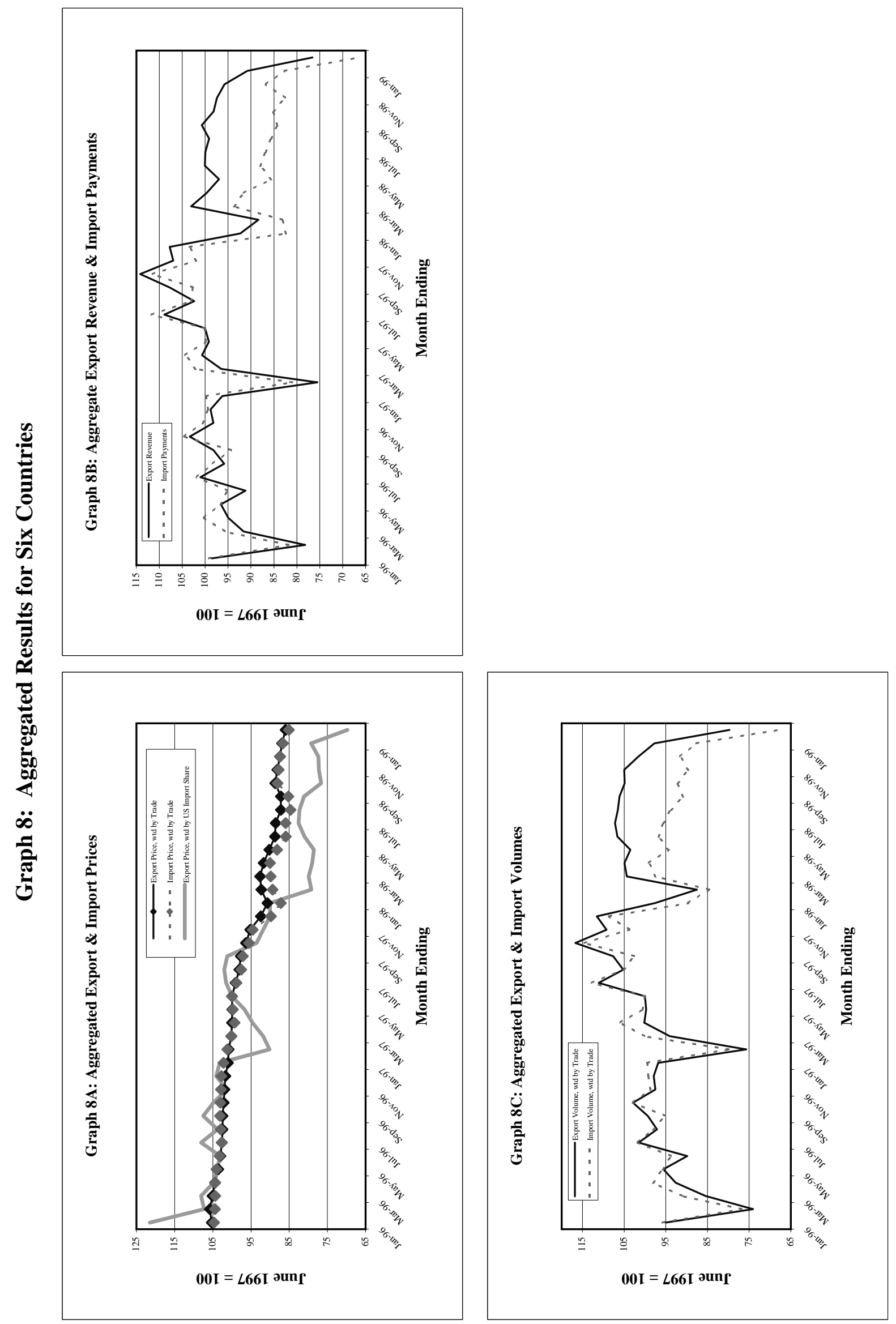